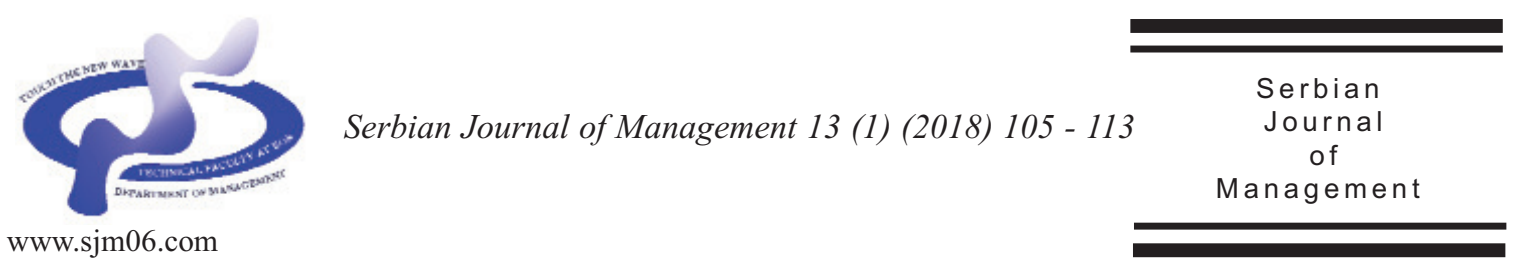

\title{
THE ROLE OF INDUSTRIAL FACTORS ON OPTIMAL CAPITAL STRUCTURE PROXY: AN EMPIRICAL STUDY ON INDONESIA MANUFACTURE COMPANIES
}

\author{
Prima Naomi $^{a^{*}}$, Irwan Adi Ekaputrab and Buddi Wibowo ${ }^{b}$

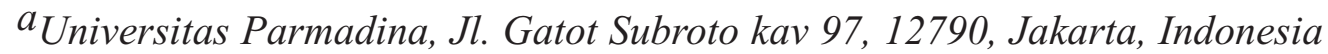 \\ $b_{F E B}$ Universitas Indonesia, Kampus UI Depok, 16424, Depok, Indonesia
}

(Received 7 January 2018; accepted 22 March 2018)

\begin{abstract}
The objective of this study is to improve the model of optimal capital structure. This research aims to investigate the role of the industrial factors on the optimal capital structure proxy by including industry factors in the existing model and using the company characteristic variables as control variables. This research applies seven industrial variables: Number of Firms in Industry (NFI), Industry Competitive Dynamic (ICD), Firm Response to Industry Competitive (FRI), Numbers of Employees in an Industry (NEI), Employees' Share of Firm Quasi Rents (ESQ), Category of Product Diversification (CPD), and Diversification level of Relatedness (DRD). This research determines whether the proposed proxy in this research is better than the two other proxies. The testing procedure is designed to replicate the procedure of Farhat (2003). The data used in the study consist of 83 companies from 13 industries listed on IDX for the period of 2001-2014. The results showed that the industry variables can improve the existing optimal capital structure proxies. This finding contributes to the industry in that it can improve the dynamic trade-off model of capital structure.
\end{abstract}

Keywords: optimal capital structure, dynamic trade-off model, industrial factors, industry competitive, employee, diversification

\section{INTRODUCTION}

At present, industrial factors have not yet received much attention regarding capital structure theory; it is not discussed extensively in major theories, including trade-off theory and pecking order theory. These theories focus more on capital structure decisions based on firms' specific characteristics. Moreever, most recent research on the capital structure relate to the industrial variables used within a static

\footnotetext{
* Corresponding author:prima.naomi@paramadina.ac.id
}

DOI: $10.5937 /$ sjm13-16216 
model, and few have used a dynamic one, while the development of the capital structure theory has clearly led to the dynamic model.

In the dynamic model, the capital structure has two main issues: the optimal capital structure and the capital structure adjustment. At present, there has not been any agreement on the optimal capital structure proxy. The need for the optimal capital structure proxy stemms from an unobservable optimal capital structure. Researchers can remedy this issue by using a model to predict its value through determinants while the complete set of those determinants are unknown and/or also unobservable (Hovakimian \& Li, 2011).

Various proxies found in the financial literature (i.e. firm mean leverage ratio, moving average leverage ratio, industry median leverage ratio, and cross-sectional regression leverage ratio) are used as measurements of the optimal capital structure by using the firm's characteristic variables as the variable explanatory, such as firm size, tangibility asset, market to book ratio, $\mathrm{R} \& \mathrm{D}$ intensity, $\mathrm{R} \& \mathrm{D}$ indicator, profitability, and depreciation. Currently, most of the dynamic capital structure studies use the optimal capital structure proxy by using cross-sectional methods of which firm characteristic variables are used as independent variables (Hovakimian et.al, 2001; Fama \& French, 2002; Korajczyk \& Levy, 2003; Flannery \& Rangan, 2006; Lemmon et.al 2008; Cook \& Tang, 2010; Hovakimian \& Li, 2011). Meanwhile, Farhat (2003) uses the trade-off theory to test the most consistent proxy of the optimal capital structure, proving that the usage of cross sectional method is not the best proxy.

Based on trade-off theory, Farhat (2003) develops the empirical method to define the true optimal capital structure. According to him, optimal capital structure happens when the capital structure maximizes the firm market value. Thus, if the firm leverage ratio deviates from its optimum state, its market value declines. This study uses the correlation between the leverage ratio and the firm value and the correlation between the firm value and the deviation from the optimal capital structure. We find that, when using Industry Median Leverage Ratio (IMLR) as a proxy, we see that $65 \%$ of all samples have a strong correlation, while when using the cross-sectional as its target, it results in only $50 \%$. Therefore, it is concluded that the IMLR is the best proxy compared to the others, followed by the cross-sectional model. Implicitly, the outcome explains that the independent variables used in the cross-sectional method have not yet been able to explain the best optimal capital structure proxy. Such a conclusion motivates further questions regarding the causes of the proxy discrepancy, which presents opportunities to look for other independent variables to fill the gap. As the IMLR is the best proxy of the optimal capital structure, it is predicted that the independent variables of the industrial factors can cover the gap. A later study by D'Mello and Farhat (2008) uses extensive data and introduces the moving average proxy of capital structure to find the best proxy. The result is that the moving average proxy is best, followed by the IMLR and the cross-sectional proxy. This finding confirms the findings of the previous study that the cross-sectional proxy is not the best for the optimal capital structure. Therefore, this study asks the following question: Do industrial factors play roles in the optimal capital structure proxy? 


\section{LITERATURE REVIEW}

In the finance literature, scholars refer to the optimal capital structure as the target leverage or the optimal debt ratio. They have the same meaning as capital structure in maximizing companies' value. Some issues on the optimal capital structure have questioned whether the target is stable or changing over time; it other words, it indicates whether the target is static or dynamic. D'Mello and Farhat (2008) argue that the proxy for the optimal leverage ratio is an important element of the study of trade off theory, because the conclusion will strongly rely on the used gauge. The main issue in the optimal capital structure is that the variable is unobservable, and the complete determinant is not only unknown and also unobservable (Hovakimian \& Li, 2011).

Several ideas have been expressed regarding the proxy of optimal capital structure in financial literature. D'Mello and Farhat (2008) mention four proxies that can be used: the firm's mean leverage ratio, moving average ratio, industry median leverage ratio, and cross-sectional regression leverage ratio. However, Leary and Roberts (2005) and Flannery and Rangan (2006) used another proxy, fixed effect leverage ratio.

Table 1 provides a summary of the proxies used by previous researchers and the purpose proxy in this research. The first four proxies have been previously mentioned in the work of Farhat (2003) to examine tradeoff theory. He sought to determine which proxy is consistent and suitable with the theory of optimal capital structure. Capital structure is considered optimal when the value of the firm is maximal. If the capital structure of the firm has a gap with the target, the firm's value will decline. By looking at the correlation between the leverage target' deviation and the firm's value, it is found that the industry's median leverage ratio is the best proxy, followed by the cross-sectional proxy. More specifically, it is found that $65 \%$ of firms follow this industry median leverage ratio when they are under their leverage target.

\section{RESEARCH METHODOLOGY}

This study employes secondary data. The main data are from the financial report obtained from IDX (Indonesia Stocks Exchange) publications. The secondary data are the industrial data presented by BPS (Indonesia Statistical Central Bureau). The initial samples of manufacturing industries in IDX include 211 firms. By applying the sampling procedure in this research, the samples used are from 83 firms of 13 industries for the period of 2001-2014.

In conducting the measurement of the capital structure adjustment, the most important thing to understand is the optimal capital structure. The motivation to develop this model is Farhat's finding (2003) that the best proxy optimal structure is the Industry Median Leverage Ratio (IMLR), which has correlation with the firm's value at $65 \%$ of the Cross-Sectional Leverage Ratio (CSRL1) by using the firm's independent variables as the proxy optimal capital structure as the second best, which has a correlation circa $50 \%$ of the firm's value. Therefore, it is appropriate to expect another independent variable which is explained by the proxy CSRL-1 and caught by IMLR. The interpretation of the result is that the leverage ratio of all firms available in the industry moves according to the industry dynamic across the time. While the proxy CSRL-1 


\section{Table 1. The Summary of Optimal Capital Structure Proxies}

\begin{tabular}{|c|c|c|c|c|}
\hline No & Proxy & Assumption & Researchers & Strength/weakness \\
\hline 1. & $\begin{array}{l}\text { Firm's mean leverage } \\
\text { ratio (FMLR): annual } \\
\text { firms' average of time } \\
\text { series capital structure } \\
\text { along the research period }\end{array}$ & $\begin{array}{l}\text { Each firm has optimal } \\
\text { capital structure that is } \\
\text { constant at all times }\end{array}$ & $\begin{array}{l}\text { Jalilvand \& Harris } \\
\text { (1984), Shyam-Sunder } \\
\text { \& Myers (1999), Byoun } \\
\text { \& Rhim (2005) }\end{array}$ & $\begin{array}{l}\text { Weakness: the target } \\
\text { leverage is constant }\end{array}$ \\
\hline 2. & $\begin{array}{l}\text { Industry Median } \\
\text { Leverage Ratio (IMLR): } \\
\text { Median ratio leverage in } \\
\text { each industry }\end{array}$ & $\begin{array}{l}\text {-Every industry has an } \\
\text { optimal leverage ratio } \\
\text {-The ratio is the target } \\
\text { of firms that are in the } \\
\text { industry } \\
\text {-The ratio moves all the } \\
\text { time depending on the } \\
\text { change of industrial } \\
\text { factors }\end{array}$ & $\begin{array}{l}\text { Hull (1999) as a proxy } \\
\text { for target leverage. } \\
\text { Survey result by Graham } \\
\& \text { Harvey (2001) }\end{array}$ & $\begin{array}{l}\text { Weakness: only valid } \\
\text { if industrial classified } \\
\text { is done right } \\
\text { Strength: has paid } \\
\text { attention to interaction } \\
\text { with environment, but } \\
\text { it cannot recognize the } \\
\text { variables of its } \\
\text { components }\end{array}$ \\
\hline 3. & $\begin{array}{l}\text { Cross sectional } \\
\text { regression leverage ratio } \\
\text { (CLRL-1): leverage } \\
\text { target is estimated by } \\
\text { conducting regression on } \\
\text { actual debt ratio along } \\
\text { with firm's factors } \\
\text { proposed by trade off } \\
\text { theory and previous } \\
\text { empirical studies }\end{array}$ & $\begin{array}{l}\text { The ratio moves along } \\
\text { the time depending on } \\
\text { the firm's characteristics } \\
\text { that are stated by the } \\
\text { theory and previous } \\
\text { empirical studies }\end{array}$ & $\begin{array}{l}\text { Hovakimian et.al. } \\
\text { (2001), Fama \& French } \\
\text { (2002), Korajczyk \& } \\
\text { Levy (2003), Flannery } \\
\text { \& Rangan (2006), } \\
\text { Lemmon et al. (2008), } \\
\text { D'Mello \& Farhat } \\
\text { (2008), Cook \& Tang } \\
\text { (2010), Hovakimian \& } \\
\text { Li (2011). }\end{array}$ & $\begin{array}{l}\text { Weakness: only able to } \\
\text { recognize firm's } \\
\text { characteristic variables } \\
\text { that become an } \\
\text { explanation in the } \\
\text { model } \\
\text { Strength: the } \\
\text { determinant that makes } \\
\text { capital structure is } \\
\text { known }\end{array}$ \\
\hline 4. & $\begin{array}{l}\text { Tobit Cross-sectional } \\
\text { ratio }\end{array}$ & & Farhat (2003) & \\
\hline 5. & $\begin{array}{l}\text { Fixed effect leverage } \\
\text { ratio }\end{array}$ & $\begin{array}{l}\text { There are specific } \\
\text { variables of firms that } \\
\text { are not observed yet that } \\
\text { consistently influence } \\
\text { the target of leverage. }\end{array}$ & $\begin{array}{l}\text { Leary \& Roberts (2005), } \\
\text { Flannery \& Rangan } \\
\text { (2006) }\end{array}$ & $\begin{array}{l}\text { Strength: it can } \\
\text { recognize specific } \\
\text { variables of firms that } \\
\text { are not observed yet } \\
\text { and consistently } \\
\text { influence leverage }\end{array}$ \\
\hline 6. & $\begin{array}{l}\text { Firm's annual moving } \\
\text { average leverage ratio } \\
\text { (MALR) }\end{array}$ & $\begin{array}{l}\text { Optimal capital } \\
\text { structure moves all the } \\
\text { time along with the } \\
\text { firm's characteristic } \\
\text { changes that move all } \\
\text { the time as well }\end{array}$ & $\begin{array}{l}\text { Jalilvand \& Harris } \\
\text { (1984), Shyam-Sunder } \\
\text { \& Myers (1999), } \\
\text { D'Mello \& Farhat } \\
\text { (2008). }\end{array}$ & $\begin{array}{l}\text { Strength: it decreases } \\
\text { the weaknesses of } \\
\text { FMLR because } \\
\text { historical information } \\
\text { increases along the } \\
\text { increasing time, and } \\
\text { optimal capital } \\
\text { structure is not } \\
\text { constant at all times }\end{array}$ \\
\hline 7. & $\begin{array}{l}\text { Cross-sectional } \\
\text { regression leverage ratio } \\
\text { - Modified (CLRL-2): } \\
\text { leverage target is } \\
\text { estimated by conducting } \\
\text { regression on actual debt } \\
\text { ratio along with the } \\
\text { firm's factors and } \\
\text { industrial factors }\end{array}$ & $\begin{array}{l}\text { The ratio moves along } \\
\text { the time depending on } \\
\text { the firm's characteristics } \\
\text { and industrial } \\
\text { characteristics }\end{array}$ & Naomi (2016). & $\begin{array}{l}\text { Weakness: it can only } \\
\text { recognize firm's } \\
\text { characteristics and } \\
\text { industrial } \\
\text { characteristics } \\
\text { explained in the model } \\
\text { Strength: the } \\
\text { determinant that makes } \\
\text { capital structure from } \\
\text { both factors is known }\end{array}$ \\
\hline
\end{tabular}


only moves towards the leverage target based on the observed firm's characteristic determinant. The determinant variable used in the CSRL-1 is unable to catch all developing dynamics in the industry. Other explanations of why the IMLR is better than the CSLR-1 are: the firms know that there are the dynamics in the industries and understand how to respond to them, but not all firms have the luxury to respond as they should, and the firms are actually able to respond to them, but it is not their priority.

These findings are in line with the argument by Hovakimian and Li (2011) that the slow speed of the capital structure adjustment in firms is caused by the fact that the adjustment towards the leverage target is not the firms' high priority or that the empirical model currently used in the literature is not well suited to identify the ways in which firms facing various tradeoffs manage their debts.

As IMRL is an industry median, it is hypothesized that other independent variables are the industrial factors. This research aims to investigate the role of the industrial factors on the optimal capital structure proxy. In order to understand this role, the Cross-Sectional Leverage Ratio method is used by adding the industrial factors as an independent variable, which is later called CSRL-2. To understand the magnitude of the role of the industrial variable on the optimal capital structure, the comparative measurement of those three proxies (CSRL-1, CRSL-2, and IMRL) are used.

The third formulation of those three different proxies for the optimal capital structure as seen in equation is (1) to (3):

$$
\text { Proxy CRSL-1: } D_{1}{ }^{*}{ }_{t i j}=\alpha_{i j} \mathbf{X}_{t-1, i j}
$$

Proxy CRSL-2:

$D_{2}{ }^{t}{ }_{t j}=\alpha_{i j} \mathbf{X}_{t-1, i j}+\gamma_{j} \mathbf{Y}_{t-1, i j}$

Proxy IMRL: $D_{3}{ }^{*}{ }_{t i j}=I M R L_{t-1, i j}$.

The measurement of capital structure uses the book value of the leverage (long-term debt to total assets). The equation (1) is the cross-sectional leverage ratio of the firm characteristics (CSRL-1) symbolized as $D_{1}{ }^{*}{ }_{t i j}$, which defines the leverage target for firm $i$ in industry $j$ in period $t\left(D^{*}{ }_{t i j}\right)$ as a function of a group of the firm characteristics' variables in the previous period $\mathbf{X}_{t-1, i j}$. This research uses five variables as applied in previous studies on this topic: growth, non-debt tax shields (NDTS), tangible assets, profitability, and company size (Pandey, 2004; Parsons \& Titman, 2009; Cook \& Tang, 2010; Kayo \& Kimura, 2011; Hovakimian \& Lee, 2011).

The equation (3) of the Industrial Leverage Ratio (IMRL) is symbolized by $D_{3}{ }^{*}{ }_{t i j}$ and is defined as the function of the industry median leverage ratio. Both proxies above have been applied by the previous researchers.

The leverage target is the research focus, namely CSRL-2, is symbolized by $D_{2}{ }^{*}{ }_{t i j}$ and defined by using the equation (2), namely optimal capital structure as the function of a set of firm characteristic variables in the previous period $\mathbf{X}_{t-1, i j}$, and the industrial variables in the previous period $\mathbf{Y}_{t-1, i j}$. This research uses seven industrial variables: number of firms in industry (NFI); industry competitive dynamic (ICD), which is used as a proxy of the industry entropy proposed by Collins and Ruefli (1992); firm response to industry competitive (FRI), which uses the entropy index of individual firms; numbers 
of employees in an industry (NEI), which is measured by using the natural logarithms of the total number of workers of large and medium industries by a 2-digit ISIC code each year; employees' share of firm quasi rents (ESQ), which is measured by the ESQ introduced by Sarig (1998); category of product diversification (CPD), which uses three diversification categories: single, related, and unrelated diversification (Kochhar \& Hitt, 1998); and diversification level of relatedness (DRD), which is calculated by using the Entropy of Jacquemin and Berry (1979).

To generate $D_{1}{ }^{*}{ }_{t i j}$ and $D_{2}{ }^{*}{ }_{t i j}$, we use Hierarchical Linear Modelling (HLM), as proposed by Kayo and Kimura (2011). We use the HLM method because the exogoneus variable uses two levels of different unit analyses, i.e. firm and industry level.

For the estimation, we applied Generalized Method Moments (GMM). Upon recomendation by Baltagi (2008), the best method to estimate the micro panel data is GMM (The Micro panel data is the panel data for which $\mathrm{N}$ (number of individuals) is large and $\mathrm{T}$ (time) is short and fixed).

This research tests whether the proposed proxy in this research is better than the two other proxies. The testing procedure includes replicating the procedure of Farhat (2003).
The base of the test was the trade-off theory stating that the capital structure is said to be optimal when the firms' value is at the maximum. When the firm capital structure has a distance from its target, the firm value declines. Operationally, the test could be conducted by seeing the correlation between the leverage ratio with the firm value and between the distance of the leverage ratio and the optimal leverage ratio with the firm value. For this study, we use the second method. By comparing those correlations of those three proxies, we could find the best proxy.

\section{RESULTS}

The mean leverage, the minimum, and the maximum of all samples are, respectively, $0.386,0.000$, and 2.984. The firm leverage, which is closer to zero, means that the firm does not use long-term debt in its financial structure. Due to space constraints, the full description of other variables in this study are not shown.

I utilized both parametric (Pearson) and non-parametric (Spearman) test correlation. The correlation between the deviation capital structure from the optimal capital structure and the firm value is presented in Table 2.

Table 2. Correlation: Deviation Capital Structure from the Optimal Capital Structure and the Firm Value

\begin{tabular}{|c|c|c|c|c|c|}
\hline$\left|\mathrm{D}-\mathrm{D}_{1} *\right|, \mathbf{F v}$ & & $\left|D_{-1}-D_{2} *\right|, F v$ & & |D-D ${ }_{3}^{*} \mid$, & \\
\hline Pearson & Spearman & Pearson & Spearman & Pearson & Spearman \\
\hline$-0.120 * *$ & $-0.189 * *$ & $-0.283 * *$ & $-0.296 * *$ & $-0.107 *$ & $-0.09 *$ \\
\hline
\end{tabular}

Note : ** and * indicate that the correlation is statistically significant at 0.05 and 0.1

D: The book of Leverage

D1*: Optimal Capital Structure using CSRL-1, see equation 1.

D2*: Optimal Capital Structure using CSRL-2, see equation 2.

D3*: Optimal Capital Structure using Industry Median Leverage Ratio, see equation 3.

Fv: Firm Value, using average stock price

Source: Data analyzed by researcher 


\section{DISCUSSION}

This result shows that all cases provide evidence of the significant negative correlation between the absolute differences of the actual capital structure and the target with the firm value. These results resemble the findings by Farhat (2003) about the negative sign of the correlation; however, they are contrast with his findings about the magnitude of the correlation. The negative sign of the correlation can be interpreted as an indication that all of these three proxies can be used to be the proxy of the optimal capital structure, based on the trade-off theory.

Regarding the magnitude of the correlation, Farhat finds that industry median is the best proxy, but it is not the case in my research. As shown in Table 2, the correlation coefficient (both of Pearson and Spearman) of the $\left|\mathrm{D}-\mathrm{D}_{3}{ }^{*}\right|, \mathrm{Fv}$, is not the highest correlation among other correlations. This means that the industry median is not the most consistent proxy based on the prediction of the trade-off model. Unlike in the US firms, Indonesian firms do not use the industry median as the benchmark of their capital structure. However, the results from Irawan (2013) provide significant evidence of hearding behavior within the firms in the Indonesian manufacturing industry. It indicates that the firms follow their capital structure peers' behavior in the industry, but the proxy used by Irawan (2012) is the mean of the capital structure industry.

Despite the importance of the above findings, it is necessary to investigate this topic further in order to answer the question about the influences of the industrial factor on the optimal capital structure. To answer this question, we can compare the correlation between $\left|\mathrm{D}-\mathrm{D}_{1}{ }^{*}\right|, \mathrm{Fv}$ and $\left|\mathrm{D}-\mathrm{D}_{2}{ }^{*}\right|, \mathrm{Fv}$. The first correlation used is the CSRI-1 model (only the characteristics of firms), and the second correlation used is the CSRL-2 model (using both firm characteristics and industry characteristics). Looking at the magnitude of correlation in Table 2, we can see that in almost all cases, both using parametric or nonparametric test, the correlation of $\left|\mathrm{D}-\mathrm{D}_{2}{ }^{*}\right|, \mathrm{Fv}$, are higher than the correlation of $\left|\mathrm{D}-\mathrm{D}_{1}{ }^{*}\right|$, Fv. It can be interpreted that the industrial factors improve the optimal capital structure model. This finding provides an answer to the call given by Hovakimian \& Li (2011) to use a better model for the capital structure adjustment test. By using the model of the optimal capital structure and the firm characteristics and industry characteristics as exogenous variables, we can develop a better understanding about the capital structure adjustment.

\section{CONCLUSION}

There are three important findings in this research. First, this result gives evidence of the significant negative correlation between the absolute differences of the actual capital structure and the target with the firm value. The negative sign of the correlation can indicate that all of these three proxies can be used as the proxy of the optimal capital structure based on the trade-off theory. These results resemble the findings by Farhat (2003) about the negative sign of the correlation. Second, regarding the magnitude of the correlation, we find that median is not the best proxy. This differs from Farhat (2003), who finds that industry is the best proxy. Unlike in US firms, Indonesian firms do not use the industry median as the 
benchmark of their capital structure. According to Irawan (2013), firms follow their capital structure peers' behavior in the industry, however the proxy used by Irawan (2012) is the mean of the capital structure industry. Third, the industrial factors improve the optimal capital structure proxy. This finding provides a response to the suggestion of Hovakimian \& Li (2011) to use a better model for the capital structure adjustment test. By using the model of the optimal capital structure, which includes the firm and industry characteristics as exogenous variables, we expect to have a better understanding of the capital structure adjustment.

\section{References}

Baltagi, B.H. (2008). Econometric Analysis of Panel Data. Chichester: John Wiley \& Sons Ltd.

Byoun, S., \& Rhim, J. (2005). Testing of the pecking order theory and tradeoff theory of optimal capital structure. The Global Business and Finance Review, 10, 1-26.

Collins, J., \& Ruefli, T. (1992). Strategic Risk: An Ordinal Approach. Management Science, 38, 1707-1731.

Cook, D.O., \& Tang, T. (2010). Macroeconomic conditions and capital structure adjustment speed. Journal of Corporate Finance, 16 (1), 73-87.

D'Mello, R., \& Farhat, J. (2008). A comparative analysis of proxies for an optimal leverage ratio. Review of Financial Economics, 17, 213-227.

Fama, F.E., \& French, R.K. (2002). Testing Trade-Off and Pecking Order Predictions about Dividents and Debt. The Review of Financial Studies, 15 (1), 1-33.

Farhat, J. B. (2003). Essays on the
Dynamics of Capital Structure. A Dissertation, University of New Orleans.

Flannery, J. M., \& Rangan, P. K. (2006). Partial Adjustment Toward Target Capital Structures. Journal of Financial Economics, 79, 469-506.

Graham, J., \& Harvey, C. (2001). The theory and practice of corporate finance: evidence from the field. Journal of Financial Economics, 60, 187-243.

Hovakimian, A., \& Li, G. (2011). In search of conclusive evidence: How to test for adjustment to target capital stucture. Journal of Corporate Finance, 17, 33-44.

Hovakimian, A., Opler, T., \& Titman, S. (2001). The debt-equity choice: An analysis of issuing firms. Journal of Financial and Quantitative Analysis, 36, 1-24.

Hull, R.M. (1999). Leverage Ratios, Industry Norms, and Stock Price Reaction: An Empirical Investigation of Stock-forDebt Transactions. Financial Management, 32-45.

Irawan, J.F.P. (2013). Interdependence of Company Capital Structure with Peer Capital Structure Through Herding Behavior on Manufacturing Companies in BEI. Jakarta: University of Indonesia.( in Indonesian)

Jacquemin, A., \& Berry, C. (1979). Entropy Measure of Diversification and Corporate Growth. Journal of Industrial Economics, 27, 359-369.

Jalilvand, A., \& Haris, R. (1984). Corporate behavior and adjusting to capital structure : The case of dual debt and equity issues. Journal of Finance, 39, 127-144.

Kayo, E. K., \& Kimura, H. (2011). Hierarchical determinats of capital structure. Journal of Banking \& Finance, 35 (2), 358371.

Kochhar, R., \& Hitt, M. (1998). Linking Corporate Strategy to Capital Structure : Diversification Strategy, Type and Source of 


\title{
УЛОГА ИНДУСТРИЈСКИХ ФАКТОРА У ОПТИМАЛНОЈ СТРУКТУРИ КАПИТАЛА: ЕМПИРИЈСКА СТУДИЈА О ПРОИЗВОДНИМ ПРЕДУЗЕһИМА ИЗ ИНДОНЕЗИЈЕ
}

\author{
Prima Naomi, Irwan Adi Ekaputra, Buddi Wibowo
}

\section{Извод}

Циљ ове студије је побољшање модела оптималне структуре капитала. Ово истраживање има за циљ да испита улогу индустријских фактора у оптималној заступљености структуре капитала тако што укључује индустријске факторе у постојећи модел, користећи карактеристичне променљиве компаније као контролне променљиве. У овом истраживању примењује се седам индустријских варијабли: број компанија у индустрији (БКИ), конкурентна динамика индустрије (КДИ), одговор компаније на конкурентност у индустрији (КИ), број запослених у индустрији (БЗИ), удео запослених у квази ренти компаније (УЗКРК), категорија диверзификације производа (КДП) и диверзификација нивоа повезаности (ДНП). Ово истраживање одређује да ли је предложени заступник у овом истраживању бољи од два друга заступника. Поступак тестирања је дизајниран да реплицира процедуру Фархата (Farhat, 2003). Подаци коришћени у истраживању састоје се од 83 компаније из 13 индустрија које су наведене на ИДКС-у за период 2001-2014. Резултати показују да промењиве у индустрији могу побољшати постојеће оптималне структуре заступњености капитала. Овај налаз доприноси индустрији у томе што може побољшати динамичан компромисни модел структуре капитала.

Кључне речи: оптимална структура капитала, динамички компромисни модел, индустријски фактори, конкурентност у индустрији, запослени, диверсификација

Financing. Strategic Management Journal, 19 (6), 601-610.

Korajczyk, R., \& Levy, A. (2003). Capital structure choice : macroeconomic conditions and financial constraints. Journal of Financial Economics, 68 (1), 75-109.

Leary, M., \& Roberts, M. (2005). Do Firm rebalance their capital structure? Journal of Finance, 60 (6), 2575-2619.

Lemmon, M., Roberts, M., \& Zender, J. (2008). Back to the Beginning: Persistence and the Cross-Section of Corporate Capital Strucure. The Journal of Finance, 63 (4), 1575-1608.

Naomi, P. (2016). Capital Structure and Industrial Factors: An Industrial Organization Perspective - Indonesia Evidence (Unpublished doctoral dissertation). Universitas Indonesia, Depok, Indonesia.

Pandey, I. (2004). Capital Structure, Profitability and Market Structure: Evidence from Malaysia. Asia Pasific Journal of Economics \& Business, 8 (2), 78-91.

Parsons, C., \& Titman, S. (2009). Empirical Corporate Finance. Dalam Handbook of Corporate Finance (hal. 204233). Amsterdam: Elsevier.

Sarig, H.O. (1998). The effect of Leverage on bargaining with a corporation. The Financial Review, 33, 1-16.

Shyam-Sunder, L., \& Myers, S. (1999). Testing static trade-off against pecking order models of capital structure. Journal of Financial Economics, 51 (2), 219-244. 